\title{
EFFECTIVENESS OF N-ACETYLCYSTEINE ON TITANIUM DIOXIDE NANOPARTICLES- INDUCED IMMUNOTOXICITY IN ADULT ALBINO RATS
}

\author{
Yassmin A. E. Mohammed*, Ghada E. A. El mesallamy*, Nanies S. Mohammed* \\ and Osama. A. Mahmoud ** \\ Forensic Medicine and Clinical Toxicology*, Medical Biochemistry **Departments \\ Faculty of Medicine - Zagazig University - Egypt
}

\begin{abstract}
Background: Titanium dioxide $(\mathrm{TiO} 2)$ is a white pigment that can be used in paints, coatings, plastics, papers, inks, medicines, pharmaceuticals, food products, cosmetics, and toothpaste. Titanium dioxide nanoparticles ( $\mathrm{TiO} 2 \mathrm{NPs}$ ) have been reported to elicit various adverse cellular effects including oxidative stress and DNA damage. $\mathrm{N}$-acetylcysteine (NAC) is an antioxidant and free radical scavenger used to combat oxidative stress-induced damage in various tissues. Aim of the Work: is to study the toxic effects of $\mathrm{TiO} 2 \mathrm{NPs}$ oral administration and the protective role of NAC on the immune system of adult male albino rats. Thirty adult male albino rats were divided into 4 groups: Group I subdivided into: Subgroup (A): negative control. Subgroup (B): positive control received $1 \mathrm{ml}$ of $5 \%$ gum acacia solution by oral gavage once daily. Group II: gavaged orally $100 \mathrm{mg} / \mathrm{kg}$ NAC once daily. Group III: gavaged orally $1200 \mathrm{mg} / \mathrm{kg}$ titanium dioxide nanoparticles (1/10 LD 50) in $1 \mathrm{ml}$ of $5 \%$ gum acacia solution as a solvent once daily. Group IV: gavaged orally $(100 \mathrm{mg} / \mathrm{kg}$ NAC then $1200 \mathrm{mg} / \mathrm{kg} \mathrm{TiO} 2 \mathrm{NPs}$ once daily. After 6 weeks rats from each group and subgroup were subjected the following biochemical parameters: Tumor necrosis factor alpha and CBC with differential count. The rats were sacrificed and spleen was dissected and subjected to histopathological examination. Cell suspension from the spleen was examined to determine the extent of DNA damage through DNA extraction and gel electrophoresis. Conclusion: TiO2 NPs induced time dependent toxic effects and DNA damage in the spleen and administration of NAC with $\mathrm{TiO} 2$ NPs offers protection against their damaging effect. Recommendation: it is recommended to increase public awareness about health impact of $\mathrm{TiO}_{2}$ nanoparticles through nonessential drug additives, food colors, toothpastes etc.to limit their ingestion.
\end{abstract}

Key Words: Titanium dioxide nanoparticles, $N$ acetylcysteine, immunotoxicity, Spleen.

Corresponding author: Dr. Yassmin Mohammed

Email: yasminelaidy2015@gmail.com

Mobile:01278397609

\section{INTRODUCTION}

T

The development of technology enables the reduction of material size from Micro to Nano scale that is not only provides benefits to scientific fields, but also has potential risks to environment and humans (Colvin, 2003). Nanotechnology is the study and manipulation of particles at the Nano scale (1-100 nm) level (Roco, 2007). A nanometer $(\mathrm{nm})$ is one billionth of a meter (10-9m), Nanoparticle (NP) refers to the primary structure, but aggregates or agglomerates of NPs also occur (Maynard and Kuempel, 2005).

Nanomaterials have created a profound impact in their application in the fields of biomedicine, commercial products and industrial practice (Jasmine et al., 2010). This is due to the unique properties of nanomaterials (e.g. chemical, mechanical, optical, magnetic, and biological) which make them desirable for commercial and medical applications (Oberdorster et al., 2005; Nel et al., 2006 and Jin et al., 2008). 
However, materials that are inert in bulk forms may be toxic in nanosize forms, and it is essential to understand the biologic activities and potential toxicity of nanomaterials (Nel et al., 2006). The unique mechanical and physicochemical properties of NPs, such as high surface area to volume ratio, abundant reactive sites on the surface, large fraction of atoms located on the exterior face as well as mobility, and biological reactivity could be one of the reasons for their interaction with biological systems (Singh and Nalwa, 2011).

Humans can be exposed to nanomaterials by different routes such as inhalation, injection, oral ingestion and the dermal route Specifically, the respiratory system, gastrointestinal tract, the circulatory system as well as the central nervous system are known to be adversely affected by nanoparticles (Medina et al., 2007).

Titanium dioxide (TiO2), also known as titanium oxide or titania is naturally occurring oxide of titanium. Its nanoparticles are white odorless fine powder, which exists in three forms, namely: rutile, anatase and brookite. There are some differences in physical (e.g. crystal structure, stability, hardness, density) and optical (e.g. color, luster, brightness, refractive index) properties between them (Markowska et al., 2011).

They are used in a variety of consumer products, as surface coatings, paints, toothpastes, sunscreens, cosmetics, food products (Magaye et al., 2012) and in the environmental decontamination of air, soil, and water (Robertson et al., 2010).

Titanium is extensively used for a wide range of implanted medical devices, such as dental implants, joint replacements, cardiovascular stents, and spinal fixation devices, due to its advantageous combination of physico-chemical and biological properties. However, under mechanical stress or altered physiological conditions such as low $\mathrm{pH}$, Ti- based implants can release large amounts of particle debris; both in the micrometer and nanometer size range (Vamanu et al., 2008).

Titanium dioxide nanoparticles also have been used in photodynamic therapy (Riu et al., 2006) and antibacterial drugs (Yuan et al., 2010). It was found that the bacterial spore destruction was attributed to the highly oxidizing radicals generated by it (Brunet et al., 2009).

It is used in cosmetic and skin care products, particularly in sunblocks, where it helps to protect the skin from ultraviolet (UV) light due to its effective ability to block longwave ultraviolet light (Trouiller et al., 2009 ; Zhang et al., 2009).

Titanium dioxide can enter the human body through different routes such as inhalation, ingestion, dermal penetration and injection (Jin et al., 2008). Inhalation and skin contact are considered most important for nanoparticles (Shukla et al., 2011).

However, the potential exposure route for general population is the oral ingestion because $\mathrm{TiO} 2$ is used as a food additive in toothpaste, capsule and cachou (Wang et al., 2007). Titanium dioxide nanoparticles have been reported to elicit various adverse cellular effects including DNA damage, apoptosis, mitochondrial abnormalities (Wiesenthal et al., 2011) and oxidative stress (Montazer et al., 2011).

The studies have been reported that exposure to $\mathrm{TiO} 2 \mathrm{NPs}$ produced immune system affection by splenocyte apoptosis (Fabian et al., 2008), change cytokine production and decrease immune function $(\boldsymbol{L i}$ et al., 2010). Also, the systemic immune response by increasing lymphocytes proliferation associated with inhalable TiO2NP provided new strategy for risk assessment of TiO2NP exposure (Sang et al., 2012). 
$\mathrm{N}$-acetylcysteine (NAC) is an antioxidant and free radical scavenger. It acts as a cysteine donor and maintains or even increases the intracellular levels of glutathione, a tripeptide which protects cells from toxins such as free radicals (Xue et al., 2011). N-acetylcysteine has been used to combat oxidative stress-induced damage in various tissues (Jain et al., 2011)

Aim of the Work: was to study and explore the toxicological impact of Titanium dioxide nanoparticles on immune system, and to evaluate the degree of effectiveness of $\mathrm{N}$ Acetylcysteine (NAC) on titanium dioxide nanoparticles (TiO2NPs) induced immunotoxicity in adult male albino rats

\section{Material and Methods}

\section{Material:}

Titanium dioxide nanoparticles $\left(\mathrm{TiO}_{2}\right.$ NPs): used as white to beige odorless fine powder dissolved in gum acacia solution. It was manufactured by Sigma-Aldrich. Gum acacia: It is presented in powder form. The solution is prepared by dissolving $10 \mathrm{gm}$ of powder in $100 \mathrm{ml}$ boiled distilled water. It was obtained from El- Nasr pharmaceutical.

N-Acetylcystiene (NAC): It was obtained from SEDICO, Egypt in the form of effervescent instant sachets, $200 \mathrm{mg}$ each. It is soluble in distilled water.

\section{Animals:}

The study was carried out on 30 adult male albino rats weighing (150-175) g; they were obtained from the Animal House in Faculty of Medicine Zagazig University. Before starting the experiment, all animals were subjected to 2 weeks of passive preliminaries for house acclimatization, to ascertain their physical well-being and to exclude any diseased animal.

The Institutional Review Board (IRB) committee for scientific research of Faculty of
Medicine, Zagazig University approved the design of the experiment. All animals received human care in compliance with the Animal Care Guidelines and Ethical Regulations in accordance with "The Guide for the Care and Use of Laboratory Animals" (Institute of Laboratory Animal Resources, 1996).

Study design: The rats were divided into 4 groups as follow:

- Group I (control group) (12 rats): which subdivided into 2 equal subgroups:

Subgroup (A) (negative control group): (6 rats): received only regular diet and water to determine the basic values of performed tests for 6 weeks

Subgroup (B) (positive control group): (6 rats): received $1 \mathrm{ml}$ of $5 \%$ gum acacia solution (the solvent of titanium dioxide) by oral gavage once daily for 6 weeks

- Group II (N-acetylcysteine treated group) (6 rats): received $100 \mathrm{mg} / \mathrm{kg}$ body weight $\mathrm{N}$ acetylcysteine once daily for 6 weeks (Jain et al., 2011).

- Group III (titanium dioxide treated group) (6 rats): received $1200 \mathrm{mg} / \mathrm{kg}$ body weight titanium dioxide nanoparticles $(1 / 10$ $\mathrm{LD}_{50}$ ) in $1 \mathrm{ml}$ of $5 \%$ gum acacia solution as a solvent once daily for 6 weeks. The LD50 of $\mathrm{TiO} 2$ for rats is more than $12,000 \mathrm{mg} / \mathrm{kg}$ after oral administration (Wang et al., 2007).

- Group IV (titanium dioxide and Nacetylcysteine treated group) (6 rats): Each rat gavaged orally with $(100 \mathrm{mg} / \mathrm{kg}$ body weight $\mathrm{N}$-acetylcysteine then $1200 \mathrm{mg} / \mathrm{kg}$ body weight titanium dioxide nanoparticles) once daily for 6 weeks.

\section{Methods:}

After 6 weeks ( 24 hours from the last dose) rats from each group and subgroup were subjected to. 
1- Blood samples collection:

Venous blood samples were collected from animals by means of micro-capillary glass tubes from the retro-orbital plexus in according to Johnson (2007).

The collected blood was used as follow: Blood samples (about $2 \mathrm{~mL}$ ) were collected in clean test tubes without anticoagulant and allowed to clot for $30 \mathrm{~min}$ at $25^{\circ} \mathrm{C}$ after which serum was separated by centrifugation of blood $3000 \mathrm{rpm}$ for $15 \mathrm{~min}$. The supernatant sera were pipette off using fine tipped automatic pipettes and stored at $-20 \mathrm{C}$ until used for estimating tumor necrosis factor alpha. Another blood samples (about $1 \mathrm{ml}$ ) were collected into test tubes with 25 micro EDTA to determine hematological parameter (CBC with differential count).

2- Spleen tissue samples collection: The rats were anesthetized by ether then sacrificed. The spleen was dissected and examined as following:

For the microscopic examination, spleen lobe from each animal was used. Spleen specimens were fixed in $10 \%$ formalin for light microscopic examination. The other spleen lobe of each rat were immediately taken and kept in physiological saline $(0.9 \%$ $\mathrm{NaCl}$ ) at $-20 \mathrm{oC}$ until used for the DNA damage assay (DNA extraction for gel electrophoresis) to determine the extent of DNA damage.

\section{Biochemical studies:}

A-Tumor necrosis factor alpha (TNF- $\alpha$ ): Tumor necrosis factor alpha (TNF- $\alpha$ ) levels were measured using various commercially available rat enzyme-linked immunosorbent assay (ELISA) kits. Specifically, for TNF- $\alpha$ levels, the invitrogen ELISA kit (catalog number KRC3011; invitrogen, carisbad, ca, USA) was used.

\section{B-Complete blood cell count (CBC) with differential count:}

Blood samples with EDTA were used for determination of hematological parameters. The complete blood count, including erythrocyte count, platelet, total and differential leucocytes were performed by using Rytoo7200 equipment.

\section{Histopathological studies:}

Macroscopic features of spleen was recorded. Then samples from the spleen were fixed in $10 \%$ formalin .After fixation, spleen was embedded in paraffin blocks and processed for the preparation of $5 \mu$ thick sections. Sections were stained with haematoxylin and eosin and examined by light microscope (Kiernan, 2001).

\section{Detection of DNA fragmentation:}

DNA laddering: It is a qualitative analysis of DNA fragmentation by agarose gel electrophoresis, the presence of DNA ladder was determined according to Wlodek et al., (1991).

Principle: Nuclear morphology changes characteristic of apoptosis appear within the cell together with a distinctive biochemical event: the endonuclease-mediated cleavage of nuclear DNA.

DNA extraction and storage: Tissue samples were coded and analyzed in blind manner for genomic DNA extraction using the commercially available G-spin ${ }^{\mathrm{TM}}$ Total DNA Extraction Kit.

Protocol used for DNA extraction from tissues was followed according to Buffone and Darlington, (1985):

Twenty five mg of ground tissue sample was measured and transferred to $1.5 \mathrm{~mL}$ micro-centrifuge tube. Then Two hundred $\mu 1$ of buffer CL (lysis buffer), $20 \mu$ l proteinase K and $5 \mu 1$ of RNase A solutions were added to each sample tube and mixed by vortixing vigorously. The lysate was incubated at $56^{\circ} \mathrm{C}$ for 30 minutes in pre heated heat block. After lysis was completed, $200 \mu \mathrm{l}$ of buffer BL 
(lysis/ binding buffer) was added into upper sample tube, mixed thoroughly and incubated at $70^{\circ} \mathrm{C}$ for $5 \mathrm{~min}$. The sample tube was centrifuged at $13,000 \mathrm{rpm}$ for 5 minutes to remove un-lysed tissue particles. Then $400 \mu 1$ of the supernatant was transferred into a new $1.5 \mathrm{~mL}$ micro-centrifuge tube. Two hundred $\mu 1$ of absolute ethanol was added to the lysate, inverted to mix for 5-6 times. The mixture was poured to the spin column (in a $2 \mathrm{~mL}$ collection tube) without wetting the rim; the cap was closed and centrifuged at 13,000 rpm for 1 minute. The filtrate was discarded and the spin column was placed in a $2 \mathrm{~mL}$ collection tube. Seven hundred $\mu$ l of buffer WA (wash buffer A) was added to the spin column without wetting the rim, and centrifuged at $13,000 \mathrm{rpm}$ for 1 minute, the flow -through was discarded and the collection tube was reused. The spin column was centrifuged at 13,000 rpm for 1 minute to dry the membrane.

The spin column was placed in a new $1.5 \mathrm{~mL}$ tube, $70 \mu \mathrm{l}$ of buffer CE (elution buffer) was directly added to the membrane, incubated for 1 minute at room temperature and then centrifuged for 1 minute at $13,000 \mathrm{rpm}$ to elute the DNA. DNA was stored at $-20^{\circ} \mathrm{C}$ until used for gel electrophoresis.

\section{Agarose gel electrophoresis:}

Reagents: Tris Acetate EDTA (TAE) buffer for electrophoresis; Ethidium bromide solution; Electrophoresis-grade agarose; Loading dye and DNA molecular weight markers (ladder).

Reagents preparations: Tris Acetate EDTA buffer stock solution (50X): $242 \mathrm{~g}$ of tris (tris hydroxymethyl aminomethane) base and 37.2 $\mathrm{g}$ of Di sodium salt of ethylene diamine tetra acetic acid ( $\mathrm{Na}_{2}$ EDTA) were dissolved in 900 $\mathrm{mL}$ of deionized water. $57.1 \mathrm{~mL}$ of glacial acetic acid was added and the final volume was adjusted with water to 1 liter $(\mathrm{pH} 8.5)$ and stored at room temperature. Ethidium bromide stock solution: $50 \mathrm{mg}$ of ethidium bromide was dissolved in $100 \mathrm{~mL}$ of $\mathrm{H}_{2} \mathrm{O}$.
The dilution used was $1: 1000$ at $4^{\circ} \mathrm{C}$ and protected from light. One percent \% Agarose gel: $2 \mathrm{~g}$ agarose was dissolved in $200 \mathrm{~mL}$ of 1X TAE buffer (in the presence of ethidium bromide) by heating until melted. The gel was poured on the tray and left to cool before loading the samples.

\section{DNA fragmentation assay:}

Quantitative analysis of DNA fragmentation by diphenylamine (DPA), DNA fragmentation was measured by the diphenylamine spectro-photometric method according to Perandones et al., (1993) with some modifications from Burton, (1956). This method is based on the notion that extensively fragmented double-stranded DNA can be separated from chromosomic DNA upon centrifugal sedimentation. The protocol includes the lysis of cells and the release of nuclear DNA, a centrifugation step with the generation of two fractions (corresponding to intact and fragmented DNA), precipitation of DNA, hydrolysis and colorimetrical quantitation upon staining with DPA, which binds to deoxyribose.

Principle: Diphenylamine reagent includes acetic acid and sulfuric acid which react with DNA and cleave the phospho-diester bonds and hydrolyze the glycosidic bonds between the sugar and purines. The free 2-deoxy ribose undergoes a dehydration reaction to form $\omega$-hydroxylevuliny aldehyde, which reacts with DPA to produce a variety of bluecolored compounds showing a characteristic absorbance peak at wave length $600 \mathrm{~nm}$.

Two hundred and Fifty $\mathrm{mg}$ tissue was weighed and was homogenated in $400 \mu$ ice cold TTE lysis buffer and vortexed vigorously. This procedure allows the release of fragmented chromatin from nuclei, after cell lysis (due to the presence of Triton X-100 in the TTE solution) and disruption of the nuclear structure (following $\mathrm{Mg}^{+2}$ chelation by EDTA in the TTE solution). Fragmented DNA was separated from intact chromatin by 
centrifugation for $15 \mathrm{~min}$ at $25000 \times \mathrm{g}, 4^{\circ} \mathrm{C}$. The supernatant containing small DNA fragments was separated immediately into another set of tubes. The supernatant, as well as the pellet containing large pieces of DNA, were used for the DPA assay. The pellet containing intact DNA was re-suspended in $400 \mu \mathrm{l}$ TTE lysis buffer. Four hundred $\mu \mathrm{l}$ of $10 \%$ TCA was added to both the supernatant and the re-suspended pellet and vortex vigorouly. Precipitation was allowed to proceed overnight at $4^{\circ} \mathrm{C}$. After incubation, DNA was recovered by pelleting for $10 \mathrm{~min}$ at $25,000 \mathrm{xg}$ at $4^{\circ} \mathrm{C}$. Supernatants were discarded by aspiration. DNA was hydrolyzed by adding $160 \mu \mathrm{l}$ of $5 \%$ TCA. The tubes were incubated at $80^{\circ} \mathrm{C}$ for 30 min in a heat block, cooled at room temperature, centrifuged at $500 \mathrm{~g}$ for $15 \mathrm{~min} 4^{\circ} \mathrm{C}$. A blank was prepared with $160 \mu \mathrm{l}$ of 5\% TCA alone. Three hundred and twenty $\mu$ l of the DPA reagent were added to one volume of the extracted DNA. All tubes were vortexed and then left overnight at room temperature to allow color to develop. The blue color was measured colorimetrically using spectrophotometer at wave length $600 \mathrm{~nm}$ (Spectronic ${ }^{\circledR}$ Gene system, 2PC, USA). The percentage of DNA fragmentation in each sample was expressed by the formula:

$$
\begin{aligned}
& \% \text { DNA fragmentation } \\
& =\frac{\text { OD of fragmented }}{\text { OD of fragmented }+ \text { OD of intact }} \times 100 \\
& \text { * OD is the optical density }
\end{aligned}
$$

\section{RESULTS}

\section{Biochemical results:}

\section{A-Tumer necrosis factor alpha (TNF-a)}

(pg/ml): The results revealed highly significant $(\mathrm{P}<0.001)$ increase in mean values of serum $(\mathrm{TNF}-\alpha)$ in Titanium dioxide treated group when compared with -ve control group. While there was highly significant $(\mathrm{P}<0.001)$ decrease in mean values of serum (TNF- $\alpha$ ) in Titanium dioxide and $\mathrm{N}$-Acetylcysteine treated group when compared with Titanium dioxide treated group (Table. 1 and Fig.1).

(B) Total Red Blood Cells (RBCs) $\left(10^{6} \% \mathrm{uL}\right)$ : The results revealed highly significant $(\mathrm{P}<$ $0.001)$ decrease in mean values of total red blood cells in Titanium dioxide treated group and Titanium dioxide and N-Acetylcysteine treated group when compared with -ve control group after 6 weeks of study (Table. 2 and Fig.2).

\section{(C) Total White Blood Cells (WBCs)} (10\%)/uL): The results revealed highly significant $(\mathrm{P}<0.001)$ increase in mean values of total white blood cells in Titanium dioxide treated group when compared with ve control group. While there was highly significant $(\mathrm{P}<0.001)$ decrease in mean values of total white blood cells in Titanium dioxide and $\mathrm{N}$-Acetylcysteine treated group when compared withTitanium dioxide treated group (Table. 3 and Fig.3).

(D) Total Platelet count $\left(\mathbf{1 0}^{3} / \mathbf{u L}\right)$ : The results revealed highly significant $(\mathrm{P}<0.001)$ decrease in mean values of total platelet count in Titanium dioxide treated group and Titanium dioxide and N-Acetylcysteine treated group when compared with -ve control group after 6 weeks of study (Table $\mathbf{. 4}$ and Fig.4).

(E) Total Lymphocytic count: The results revealed significant $(\mathrm{P}<0.001)$ increase in mean values of total lympocytic count in Titanium dioxide treated group when compared with -ve control group. While there was significant $(\mathrm{P}<0.001)$ decrease in mean values of total lympocytic count in Titanium dioxide and $\mathrm{N}$-Acetylcysteine treated group when compared with Titanium dioxide treated group (Table. 5 and Fig.5).

(F) Total Neutrophilic count: The results revealed significant $(\mathrm{P}<0.001)$ increase in mean values of total neutrophilic count in Titanium dioxide treated group when compared with -ve control group. While there was significant $(\mathrm{P}<0.001)$ decrease in mean values of total neutrophilic count in Titanium dioxide and $\mathrm{N}$-Acetylcysteine treated group when compared withTitanium_dioxide treated group (Table. 6 and Fig.6). 
(G) Total Monocytic count: The results revealed highly significant $(\mathrm{P}<0.001)$ increase in mean values of total monocytic count in Titanium dioxide treated group when compared with -ve control group. While there was significant $(\mathrm{P}<0.001)$ decrease in mean values of total monocytic count in Titanium dioxide and $\mathrm{N}$-Acetylcysteine treated group when compared with Titanium_dioxide treated group (Table. 7 and Fig.7).

\section{Histopathological results:} control group and NAC group: Light microscopic examination of spleen of negative control, positive control and NAC showing normal splenic tissue in the form of normal spleen tissue with thin connective tissue capsule from which short trabecula extend to spleen architecture, intact white pulp of normal size formed of aggregates of lymphocyte around the central vein that well distinct from a clear red pulp formed of blood sinusoids filled with lymphocyte and RBCs (Fig 8).

\section{Titanium dioxide treated group:} Microscopic examination of the spleen specimens of the rats of this group revealed the following histopathological changes: shrinkage and decrease in size in one lymphoid follicle with hypocellularity in another one, congestion of the red pulp, accumulation of macrophages in red pulp (Fig 9, 10, 11).
Titanium dioxide and NAC treated group: Microscopic examination of the spleen specimens of the rats of this group revealed significant improvement of histopathological changes compared with tissues from rates treated with Titanium dioxide alone (Fig 12).

\section{DNA gel electrophoresis result:}

Titanium dioxide treated group: Administration of titanium dioxide $1200 \mathrm{mg} / \mathrm{kg}$ body weight once daily for 6 weeks resulted in advanced or severe shearing of DNA extracted from spleen and lymph nodes (Fig.13: Lanes 5,7,9,10,11,12,13,14 Upper raw), (Lanes 1,2,3, 6,12,13,19 Lower raw).

Titanium dioxide and $\mathrm{N}$-Acetylcysteine treated group: Administration of $(100 \mathrm{mg} / \mathrm{kg}$ body weight $\mathrm{N}-\mathrm{A}$ cetylcysteine then 1200 $\mathrm{mg} / \mathrm{kg}$ body weight Titanium dioxide) once daily for 6 weeks resulted in regression of DNA shearing extracted from spleen and lymph nodes (Fig.14: lanes 1,2,3,4,6,8 UPPER raw), (lanes 7,8,9,10,11,20,21 Lower raw).

DNA fragmentation assay in study groups Table (8): This table showed that, there was statistical significant difference between study groups in DNA damage assay $(\mathrm{p}<0.001)$.in groups I, II DNA was normal. While in groups III, IV DNA was damaged in spleen Tissues.

Table (1): Least significant difference (LSD) For comparison between negative control, $\mathrm{TiO}_{2}$ treated , NAC+ $\mathrm{TiO}_{2}$ treated groups after 6 weeks of the study as regard mean values of serum tumor necrosis factor alpha (TNF- $\alpha$ ).

\begin{tabular}{l|l|l|l|l|}
\hline & -ve control & NAC group & $\mathbf{T i O}_{2}$ \\
\cline { 2 - 5 } & NAC group & $0.01^{*}$ & & $<0.001 * *$ \\
\cline { 2 - 5 } & $\mathbf{T i O}_{2}$ & $<0.001^{* *}$ & $<0.001^{* *}$ & \\
\cline { 2 - 4 } & $\mathbf{N A C}+\mathbf{T i O}_{2}$ & $0.036^{*}$ & 0.551 & $<0.001^{* *}$ \\
\hline
\end{tabular}


Table (2):- Least significant difference (LSD) For comparison between -ve control, $\mathrm{TiO}_{2}$ treated , $\mathrm{NAC}_{+} \mathrm{TiO}_{2}$ treated groups after 6 weeks of the study as regard mean values of total red blood cells (RBCs).

\begin{tabular}{|c|c|c|c|}
\hline & -ve control & NAC group & TiO $_{2}$ \\
\hline NAC group & $0.01 *$ & & $<0.001 * *$ \\
\hline $\mathbf{T i O}_{2}$ & $<0.001 * *$ & $<0.001 * *$ & \\
\hline NAC+ $\mathbf{T i O}_{2}$ & $<0.001 * *$ & $<0.001 * *$ & $0.004 *$ \\
\hline
\end{tabular}

* Significant **Highly Significant $\quad$-ve: negative $\mathrm{NAC}: \mathrm{N}$-Acetylcysteine $\mathrm{TIO}_{2}$ : Titanium dioxide $\mathrm{N}=\mathrm{Number}$ of sacrificed rats for each group was 6 rats.

Table (3): Least significant difference (LSD) For comparison between -ve control, $\mathrm{TiO}_{2}$ treated, $\mathrm{NAC}+\mathrm{TiO}_{2}$ treated groups after 6 weeks of the study as regard mean values of total white blood cells(WBCs).

\begin{tabular}{|l|l|l|l|}
\hline & -ve control & NAC group & TiO $_{2}$ \\
\hline NAC group & $<0.001^{* *}$ & & $0.005^{*}$ \\
\hline $\mathbf{T i O}_{2}$ & $<0.001^{* *}$ & $0.005^{*}$ & \\
\hline $\mathbf{N A C}+\mathbf{T i O}_{2}$ & $0.035^{*}$ & $<0.001^{* *}$ & $<0.001^{* *}$ \\
\hline
\end{tabular}

* Significant ** Highly Significant $\quad$-ve: negative $\mathrm{NAC}: \mathrm{N}$-Acetylcysteine $\quad \mathrm{TIO}_{2}$ : Titanium dioxide N $=\mathrm{Number}$ of sacrificed rats for each group was 6 rats.

Table (4): Least significant difference (LSD) For comparison between -ve control, $\mathrm{TiO}_{2}$ treated, $\mathrm{NAC}_{+} \mathrm{TiO}$ treated groups after 6 weeks of the study as regard mean values of total platelet count.

\begin{tabular}{l|l|r|l|l|}
\hline & -ve control & NAC group & TiO $_{2}$ \\
\cline { 2 - 5 } & NAC group & $<0.001^{* *}$ & & $<0.001^{* *}$ \\
\cline { 2 - 5 } & $\mathbf{T i O}_{2}$ & $<0.001^{* *}$ & $<0.001^{* *}$ & \\
\cline { 2 - 5 } & $\mathbf{N A C + \mathbf { T i O } _ { 2 }}$ & $0.04^{*}$ & $<0.001^{* *}$ & $.048^{*}$ \\
\hline
\end{tabular}

Table (5): Least significant difference (LSD) For comparison between -ve control, $\mathrm{TiO}_{2}$ treated, $\mathrm{NAC}+\mathrm{TiO}_{2}$ treated groups after 6 weeks of the study as regard mean values of total lymphocytic count.

\begin{tabular}{|l|l|l|l|}
\hline & -ve control & NAC group & $\mathbf{T i O}_{2}$ \\
\hline NAC group & $0.032^{*}$ & & $0.038^{*}$ \\
\hline $\mathbf{T i O}_{2}$ & $0.014^{*}$ & $0.038^{*}$ & \\
\hline $\mathbf{N A C}+\mathbf{T i O}_{2}$ & $<0.001^{* *}$ & $0.001^{*}$ & $0.05^{*}$ \\
\hline
\end{tabular}

* Significant **Highly Significant $\quad$-ve: negative $\mathrm{NAC}: \mathrm{N}$-Acetylcysteine $\mathrm{TIO}_{2}$ : Titanium dioxide $\mathrm{N}=\mathrm{Number}$ of sacrificed rats for each group was 6 rats. 
Table (6): Least significant difference (LSD) For comparison between -ve control, $\mathrm{TiO}_{2}$ treated, $\mathrm{NAC}_{+} \mathrm{TiO}$ treated groups after 6 weeks of the study as regard mean values of total neutrophilic count.

\begin{tabular}{|c|c|c|c|}
\hline & -ve control & NAC group & TiO $_{2}$ \\
\hline NAC group & $0.048^{*}$ & & $0.006^{*}$ \\
\hline $\mathbf{T i O}_{2}$ & $0.008^{*}$ & $0.006^{*}$ & \\
\hline NAC+ $\mathbf{T i O}_{2}$ & $<0.001^{* *}$ & $<0.001^{* *}$ & $0.017^{*}$ \\
\hline
\end{tabular}

* Significant ** Highly Significant $\quad$-ve: negative $\mathrm{NAC}: \mathrm{N}$-Acetylcysteine $\mathrm{TIO}_{2}$ : Titanium dioxide $\mathrm{N}=\mathrm{Number}$ of sacrificed rats for each group was 6 rats.

Table (7):- Least significant difference (LSD) For comparison between -ve control, $\mathrm{TiO}_{2}$ treated, $\mathrm{NAC}+\mathrm{TiO}$ treated groups after 6 weeks of the study as regard mean values of total monocytic count.

\begin{tabular}{cccc}
\hline & -ve control & $\begin{array}{c}\text { NAC } \\
\text { group }\end{array}$ & $\mathrm{TiO}_{2}$ \\
\hline NAC group & 0.666 & & $\mathbf{0 . 0 1 7} *$ \\
\hline $\mathrm{TiO}_{2}$ & & $\mathbf{0 . 0 1 7}^{*}$ & \\
\hline $\mathrm{NAC}^{*} \mathrm{TiO}_{2}$ & & & \\
\hline
\end{tabular}

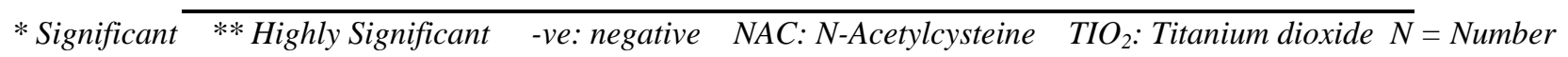
of sacrificed rats for each group was 6 rats.

Table (8) DNA fragmentation assay in study groups.

\begin{tabular}{|c|c|c|c|c|c|}
\hline & up & DNA fragn & & \multirow[b]{2}{*}{$\mathbf{X} 2$} & \multirow[b]{2}{*}{$\mathbf{P}$} \\
\hline \multicolumn{2}{|c|}{ Parameters } & $\begin{array}{c}\text { No } \\
\text { No. }(\%)\end{array}$ & $\begin{array}{c}\text { Yes } \\
\text { No. }(\%)\end{array}$ & & \\
\hline \multirow{2}{*}{ Control group (I) } & $\mathbf{A}$ & $6(100.0)$ & $0(0.0)$ & \multirow{5}{*}{23.18} & \multirow{5}{*}{$<0.001 * *$} \\
\hline & B & $6(100.0)$ & $0(0.0)$ & & \\
\hline \multicolumn{2}{|c|}{ NAC group (II) } & $6(100.0)$ & $0(0.0)$ & & \\
\hline \multicolumn{2}{|c|}{ TiO2 group (III) } & $0(0.0)$ & $6(100.0)$ & & \\
\hline \multicolumn{2}{|c|}{ NAC+ TiO2 group (IV) } & $4(66.7)$ & $2(33.3)$ & & \\
\hline
\end{tabular}

P: probability. No: number \%: percent. **: highly significant $n A C: N$-Acetylcysteine TIO $_{2}$ : Titanium dioxide. $N=$ Number of sacrificed rats for each group was 6 rats.

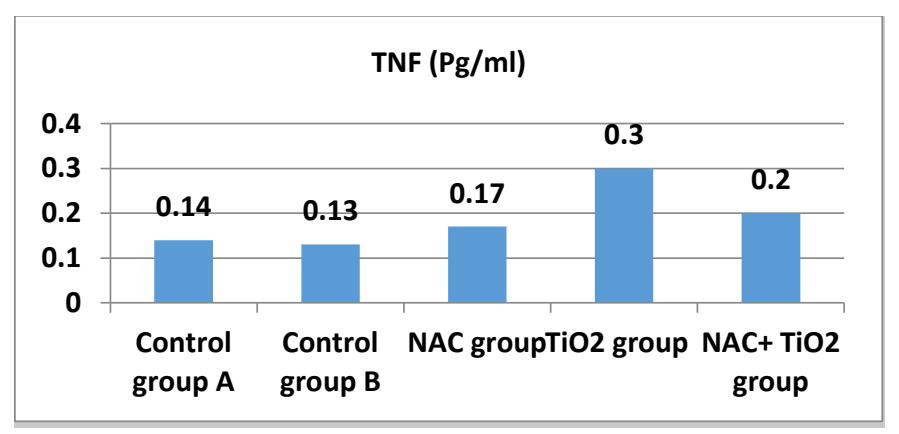

Fig. (1):Bar chart showing comparison between control groups, $\mathrm{NAC}$ treated group, $\mathrm{TiO}_{2}$ treated group and NAC+ $\mathrm{TiO}_{2}$ treated group as regard mean values of serum TNfa after 6 weeks. 


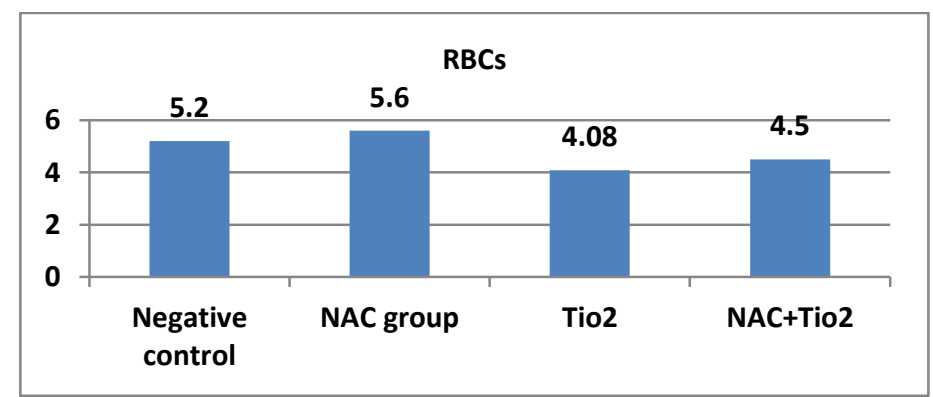

Fig. (2):- Bar chart showing comparison between control groups, $\mathrm{NAC}$ treated group, $\mathrm{TiO}_{2}$ treated group and NAC+ $\mathrm{TiO}_{2}$ treated group as regard mean values of total red blood cells after 6 weeks.

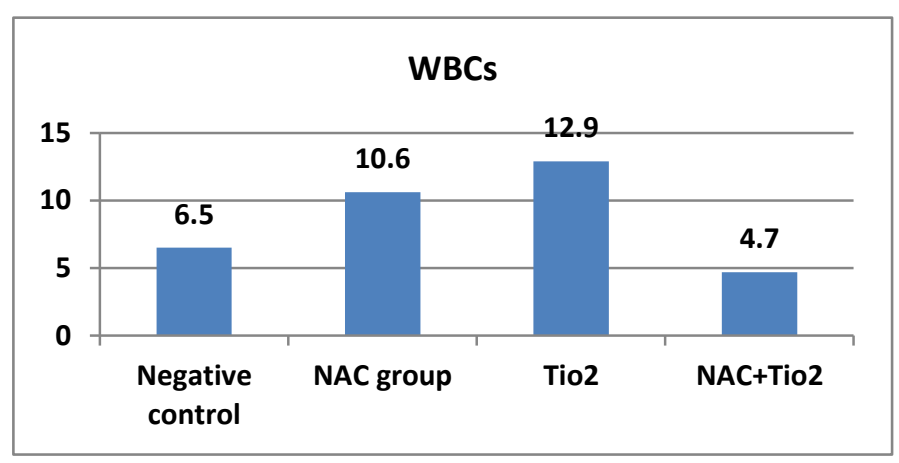

Fig. (3):- Bar chart showing comparison between control groups, $\mathrm{NAC}$ treated group, $\mathrm{TiO}_{2}$ treated group a blood cells after 6 weeks.nd $\mathrm{NAC}+\mathrm{TiO}_{2}$ treated group as regard mean values of total white

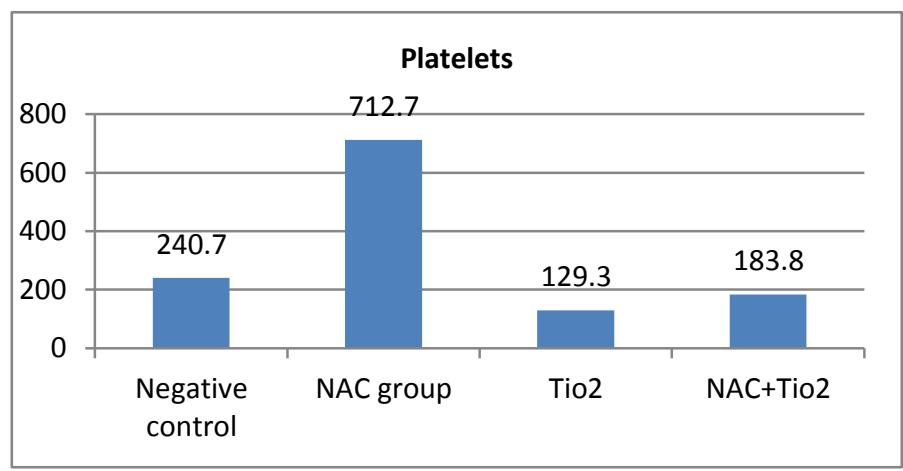

Fig.(4):- Bar chart showing comparison between control groups, $\mathrm{NAC}$ treated group, $\mathrm{TiO}_{2}$ treated group and $\mathrm{NAC}+\mathrm{TiO}_{2}$ treated group as regard mean values of total platelet count after 6 weeks.

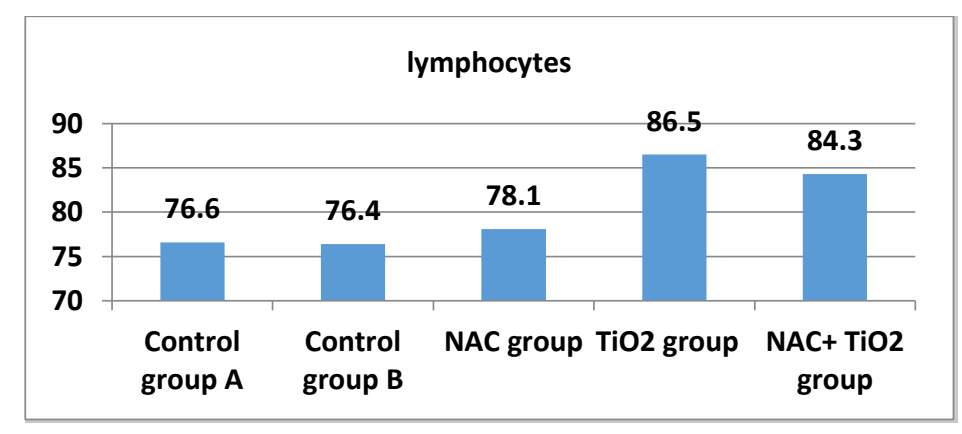

Fig. (5):- Bar chart showing comparison between control groups, NAC treated group, $\mathrm{TiO}_{2}$ treated group and $\mathrm{NAC}+\mathrm{TiO}_{2}$ treated group as regard mean values of total lymphocytic count after 6 weeks of study. 


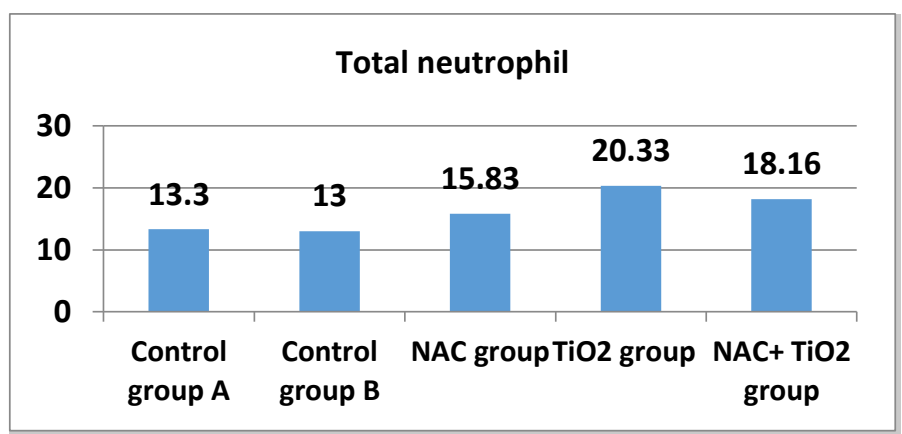

Fig. (6):- Bar chart showing comparison between control groups, $\mathrm{NAC}$ treated group, $\mathrm{TiO}_{2}$ treated group and $\mathrm{NAC}+\mathrm{TiO}_{2}$ treated group as regard mean values of total neutrophilic count after 6 weeks.

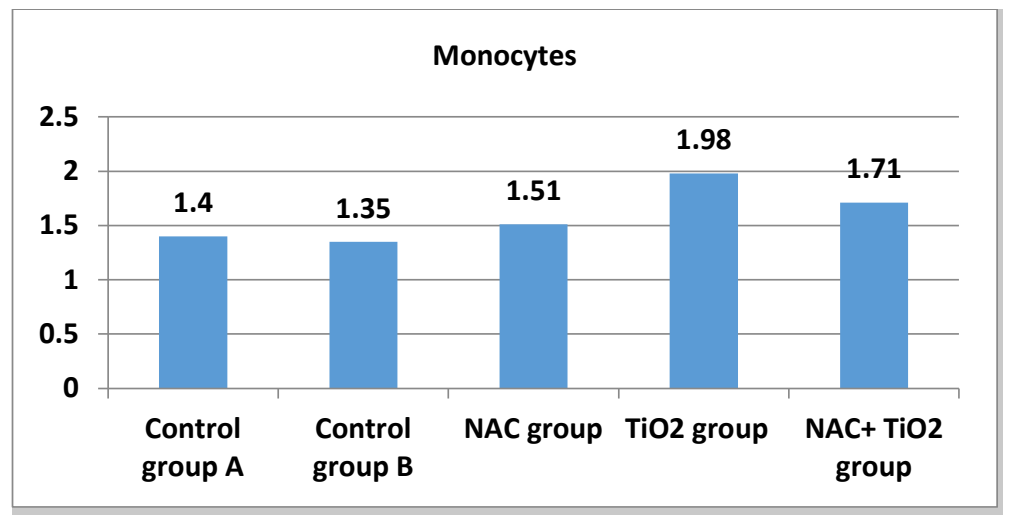

Fig. (7):- Bar chart showing comparison between control groups, $\mathrm{NAC}$ treated group, $\mathrm{TiO}_{2}$ treated group and $\mathrm{NAC}+\mathrm{TiO}_{2}$ treated group as regard mean values of total monocytic count after 6 weeks.

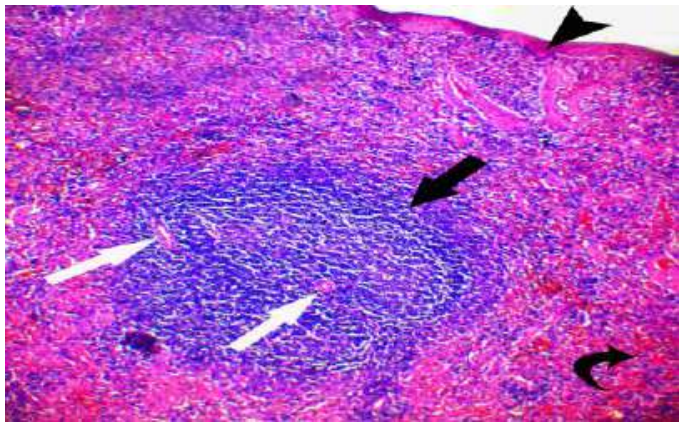

Fig.(8): photomicrograph of spleen of positive control adult male albino rate showing normal spleen tissue with thin connective tissue capsule (arrow-head) from which short trabecula extend to spleen architecture, intact white pulp (black-arrow) of normal size formed of aggregates of lymphocyte around the central vein (white-arrow) that well distinct from a clear red pulp (curved-arrow) formed of blood sinusoids filled with lymphocyte and RBCs. ( $H$ and $E, X 100)$.

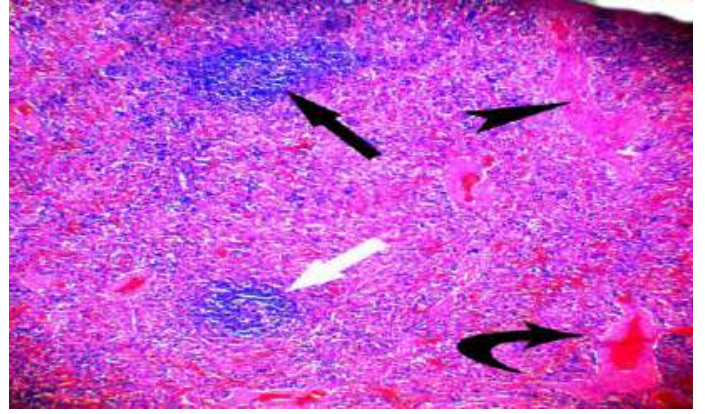

Fig.(9) : photomicrograph of spleen of adult male albino rate received titanium dioxide for 6 weeks showing thick trabecula with disruption of splenic white pulp architecture in the form of shrinkage and decrease in size in one lymphoid follicle (black-arrow), atrophy (white-arrow) and hypo cellularity in the other one with moderate congestion of the red pulp (curved-arrow).( $H$ and $E, X 100)$. 


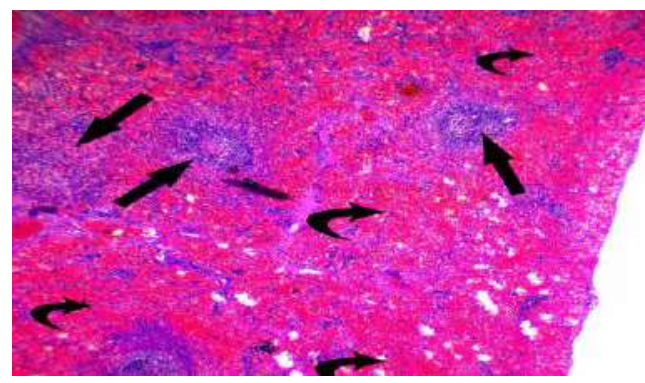

Fig.(10): photomicrograph of spleen of adult male albino rate received titanium dioxide for 6 weeks showing shrinkage and hypo cellularity of multiple lymphoid follicles (black-arrows) with fading away of its well circumscribed architecture with sever congestion of the red pulp (curved-arrows), $H$ and $E, X$ 100).

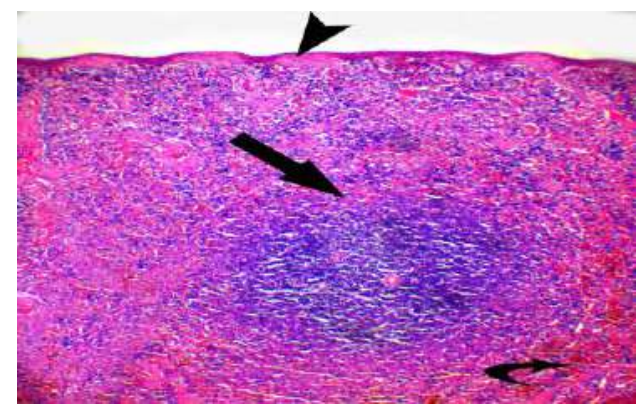

Fig .(12): photomicrograph of spleen of adult male albino rate received titanium dioxide and $\mathrm{N}$-acetylcystein showing spleen tissue with thin connective tissue capsule (arrow-head) with minimal changes in white pulp in form of loss of demarcated bounders of the lymphoid follicle (arrow) and mild congestion of the red pulp (curved-arrow).( $H$ and $E, X 100)$.

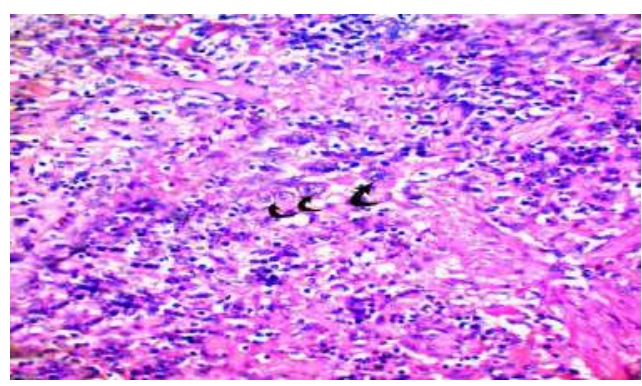

Fig. (11): photomicrograph of spleen of adult male albino rate received titanium dioxide for 6 weeks showing red pulp with accumulation of macrophages (curved-arrows), ( $H$ and $E, X$ 400).

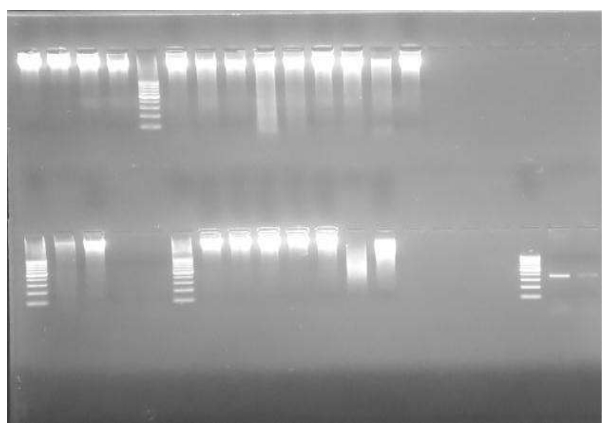

Fig.(13): Agarose gel electrophoresis of DNA isolated from spleen tissues DNA ladder assay showed advanced fragmentation of DNA lanes 5,7,9,10,11,12,13,14 Upper raw),(lanes 1,2,3, 6,12,13,19 Lower raw).

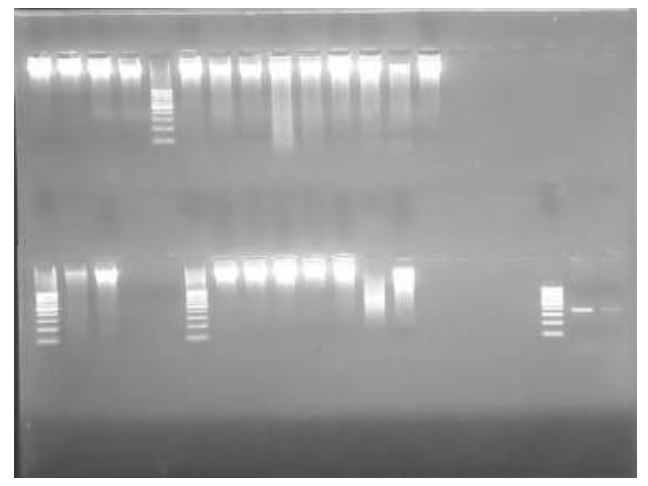

Fig.(14): Agarose gel electrophoresis of DNA isolated from spleen tissues DNA ladder assay showed mild fragmentation of DNA lanes 1,2,3,4,6,8 UPPER raw ),(lanes 7,8,9,10,11,20,21 Lower raw).

\section{DISCUSSION}

The result of the existing study revealed that there was a significant increase in TNF- $\alpha$ mean values in $\mathrm{TiO}_{2} \mathrm{Nps}$ treated group compared to their corresponding values in control groups while there was a significant increase in TNF- $\alpha$ mean values in $\mathrm{TiO}_{2} \mathrm{Nps}$ treated group compared to their corresponding 
values in NAC treated group. Palomäki et al., (2010) found that exposure of macrophages to titanium dioxide strongly enhanced the expression of interleukin-6 and TNF- $\alpha$. Sang et al., (2012) observed that, increased level of nucleic factor-kappa B , $\mathrm{TNF}-\alpha$ and interleukin secretion and decreased immunoglobulin and lymphocyte subsets in mices exposed to long time intragastric exposure to $\mathrm{TiO}_{2} \mathrm{NPs}$ accampanyed by serious spleen injury . Furthermore, $\mathrm{TiO}_{2}$ NPs activated immune cells, caused reactive oxygen species production that cause upregulation of secreted pro-inflammatory factors, such as IL- $1 \beta, \mathrm{TNF}-\alpha, \mathrm{IFN}-\gamma$ and IL- 10 (Scherbart et al., 2011). Titanium dioxide might increase the rate of cytochrome responsive gene (CYP1A) and the inflammatory marker (TNF- $\alpha$ ) mRNA transcription by inducing metabolic stress (Luo et al., 2009; Zhao et al., 2009 and Hussain et al., 2010 ).Cui et al., (2011) found that the intragastric administration of $\mathrm{TiO}_{2}$ nanoparticles causes both an increase in the mRNA and protein expression of the pro-inflammatory TLR2, TLR4, NF-kB , and TNF- $\alpha$, as well as the significant decrease in the mRNA and protein expression of the potent pro-inflammatory mediator, IL-2. Treatment of macrophages with even very low concentrations of $\mathrm{TiO}_{2}$ nanoparticles $(7 \mathrm{mg} / \mathrm{m} \mathrm{L})$ such as might be found in consumer products has been found to induce upregulation of proinflammatory gene expression suggesting that $\mathrm{TiO}_{2}$ nanoparticles exert immunomodulatory effects that are independent of an effect on cell viability (Giovanni et al., 2015).

The result of the existing study also revealed that there was a significant decrease in total red blood cells mean values in $\mathrm{TiO}_{2}$
Nps treated group compared to their corresponding values in control groups, while there was a significant decrease in total red blood cells mean values in $\mathrm{TiO}_{2} \mathrm{Nps}$ treated group and their corresponding values in NAC treated group. The interaction of titanium dioxide nanoparticles with cells and its macromolecular components is critical they might create pores in the cell membranes that could lead to toxicity by disrupting the balance of intracellular/extracellular ions, proteins and other important macromolecules that lead to change in osmotic fragility of red blood cells and a significant increase in the percentage of hemolysis (Manosij et al., 2013). $\mathrm{TiO}_{2}-\mathrm{NP}$ trans-membrane insertion breaks the erythrocytes causing hemolysis ( $\boldsymbol{L i}$ et al., 2008).

The result of the existing study revealed that there was a significant increase in total white blood cells mean values in Tio2 Nps treated group compared to their corresponding values in control groups while there was a significant increase in total white blood cells mean values in $\mathrm{TiO}_{2} \mathrm{Nps}$ treated group compared to their corresponding values in NAC treated group.

Zhangjian et al., (2015). found that significant inflammatory response by increasing concentration of TNF-a and IL-6 in rats after daily oral exposure to $\mathrm{TiO}_{2} \mathrm{NPs}$ at $50 \mathrm{mg} / \mathrm{kg}$ for 90 days lead to increased white blood cells count (WBC) and granulocytes (GRN) indicating that long-term exposure to $\mathrm{TiO}_{2}$ NPs at lower doses can also induce inflammatory response .

Djordjevich et al., (2012) also stated that Increased white blood cells count (WBC) and granulocytes (GRN) were observed in female rats treated with $50 \mathrm{mg} / \mathrm{kg} \mathrm{TiO}_{2} \mathrm{NPs}$ daily for 
90 days related to inflammatory response of the body. Titanium dioxide nano particlesrelated upregulation of systemic inflammation, assessed by increased white cell count, was provided by several studies (Nemmar et al., 2011). The result of the existing study revealed that there was a significant decrease in total platelet count mean values in $\mathrm{TiO}_{2} \mathrm{Nps}$ treated group compared to their corresponding values in control groups, while there was a significant decrease in total platelet count mean values in Tio2 Nps treated group and their corresponding values in NAC treated group.

Nemmar et al., (2008) stated that a reduced number of platelets in vivo due to a possible aggregation confirming the results obtained by the same authors in vitro.

The result of the existing study revealed that there was a significant increase in peripheral blood lymphocytes values in $\mathrm{TiO}_{2}$ Nps treated group compared to their corresponding values in control groups while there was a significant increase in peripheral blood lymphocytes mean values in $\mathrm{TiO}_{2}$ Nps treated group compared to their corresponding values in NAC treated group. $\boldsymbol{F u}$ et al., (2014) found that the twice weekly intratracheal administration of $32 \mathrm{mg} / \mathrm{kg}$ of titanium dioxide nanoparticles to Spraguee Dawley rats results in an increase in both $\mathrm{T}$ and $\mathrm{B}$ lymphocyte proliferation and enhanced natural killer cell activity related to significantly elevated levels of the pro-inflammatory cytokines IL-1, TNFa, and IL-6. Park et al., (2009) also showed an increase in numbers of $B$ cells in splenocytes and in blood after mice were treated with nano- $\mathrm{TiO}_{2}$ by a single intratracheal instillation . Gustafsson et al., (2011) discussed an increase in numbers of $\mathrm{NK}$ cells in lung after exposure to nano- $\mathrm{TiO}_{2}$ by intratracheal installation .

The current study showing that there was a significant increase in peripheral blood lymphocytes values in $\mathrm{TiO}_{2}$ Nps treated group compared to their corresponding values in control groups while there was a significant increase in peripheral blood lymphocytes mean values in $\mathrm{TiO}_{2}$ Nps treated group compared to their corresponding values in NAC treated group. Hassanein and El-Amir .(2017) who stated that $\mathrm{TiO}_{2}$ NPs induce toxicity and significantly increase the total leukocytic count, lymphocytes and neutrophils as well as TNF- $\alpha$ serum level in rats received $\mathrm{TiO}_{2} \mathrm{NPs}(150 \mathrm{mg} / \mathrm{kg}$ bw) for 6 weeks related to upregulation of systemic inflammation.

The current study showed that there was a significant increase in peripheral blood monocyte mean values in $\mathrm{TiO}_{2} \mathrm{Nps}$ treated group compared to their corresponding values in control groups while there was asignificant increase in peripheral blood monocyte mean values in $\mathrm{TiO}_{2} \mathrm{Nps}$ treated group compared to their corresponding values in NAC treated group. Bu et al., (2010) stated that significant increase in white blood cells and monocytes counts in the peripheral blood of the Wistar rats was observed following intragastrically administrated with $0,0.16,0.4$ and $1 \mathrm{~g} / \mathrm{kg}$ body weight (BW) $\mathrm{TiO}_{2}$ NPs, respectively, once a day for 14 consecutive days suggesting that $\mathrm{TiO}_{2}$ NPs may induce inflammation. Chen et al., (2015) observed that increased white blood cells count (WBC), lympocytes, monocytes and granulocytes $(\mathrm{GRN})$ in rats after daily oral exposure to $\mathrm{TiO}_{2} \mathrm{NPs}$ at $50 \mathrm{mg} / \mathrm{kg}$ for 90 days, indicating that long-term exposure to $\mathrm{TiO}_{2}$ 
NPs at lower doses can also induce inflammatory response.

The results of the present work showed that $\mathrm{TiO}_{2} \mathrm{NPs}$ induced several histopathological alterations in the spleen as compared to control groups. After 6 weeks of exposure the spleen showed thick trabecula with disruption of splenic white pulp architecture in the form of shrinkage and hypo cellularity of multiple lymphoid follicles with fading away of its well circumscribed architecture with sever congestion, accumulation of macrophages at the red pulp.

Chen et al., (2009) who observed that $\mathrm{TiO}_{2}$ NPs caused a severe lesion of spleen with congestion and accumulation of neutrophilic cells in spleen tissues by intraperitoneal injection, revealing that inflammation in spleen tissues. Studies indicates that the splenocyte apoptosis and atrophy of mice may be triggered by $\mathrm{TiO}_{2}$ NPs activation of apoptogenic factors and apoptosis-inducing factor and ROS accumulation that resulted in disruption of spleen tissue, and apoptosis suggesting that $\mathrm{TiO}_{2}$ NPs can potentially change the apoptotic genes and their proteins expression and trigger apoptosis in mitochondria-dependent pathways in the mouse spleen ( Li et al ., 2010.

Sang et al., (2012) showed that doses of 2.5, 5 and $10 \mathrm{mg} / \mathrm{kg}$ nano- $\mathrm{TiO}_{2}$ administrated by intragastric injection for 90 days produced congestion in the mouse spleen. Chen et al., (2009) found that a large number of $\mathrm{TiO}_{2}$ particles accumulated in spleen, and caused a mass of neutrophilic cells in spleen tissues and a severe spleen lesion after nano- $\mathrm{TiO}_{2}$ exposure with higher doses (324-2592 $\mathrm{mg} / \mathrm{kg}$ ) by an intraperitoneal injection for 7 days indicating inflammation of spleen tissue.
In the present study DNA fragmentation and gell electrophoresis performed on the spleen specimen revealed a significant increase in fragmented DNA in the form of both laddered and sheared DNA fragment in $\mathrm{TiO}_{2}$ NPs treated group as compared to control groups and NAC treated group. Park et al., (2008) stated that some in vitro studies have shown that nano- $\mathrm{TiO}_{2}$ can cause oxidative stress, DNA damage and enzymatic activity changes, followed by cell apoptosis or necrosis. Oral administration to Spraguee Dawley rats of $0,10,50$ or $200 \mathrm{mg} / \mathrm{kg} \mathrm{TiO} 2$ nanoparticles every day for 30 days induces double strand breaks in the DNA of bone marrow cells and /or peripheral blood (Chen et al., 2014). Abdel Azim et al., (2015) also demonstrated that $\mathrm{TiO}_{2}$ NPs-induced DNA damage is oxidative stress-dependent as the ROS react with the DNA molecule, causing damage to the purine and pyrimidine bases of the DNA backbone, resulting in apoptosis and cell death.

In the present work, at the end of $6^{\text {th }}$ week, administration of NAC with $\mathrm{TiO}_{2} \mathrm{NPs}$ caused significant decrease in serum level of TNF- $\alpha$ mean values and significant decrease in total white blood cell count, lymphocytes count, total neutrophilic count, and total monocyte count mean values, significant decrease in DNA fragmentation as compared to their corresponding in $\mathrm{TiO}_{2}$ NPs treated group. $\boldsymbol{E l}$ Kirdasy et al., (2014) who reported that Tio2 NPs cytotoxicity is aresult of oxidative stresses and can be prevented through treatment with antioxidant $\mathrm{N}$-acetylcysteine. Xue et al. , (2011) stated that NAC strongly inhibited ROS production in $\mathrm{TiO}_{2}$ treated cells and suppressed nano- $\mathrm{TiO}_{2}$ induced lipid peroxidation, and apoptosis. N-Acetyl cysteine (NAC) inhibits the release of TNF- $\alpha$, the activation of proinflammatory cytokines, 
and cellular apoptosis (El-Sayed et al., 2010). Shi et al., (2013) reported that NAC supplementation inhibited the level of $\mathrm{TiO}_{2}$ NPs induced DNA damage.

\section{CONCLUSION}

Titanium dioxide nanoparticle oral exposurelead to increase Tumor necrosis factor alpha, significant changes in $\mathrm{CBC}$, DNA damage in spleen and also induces immunotoxic changes in spleen structure. $\mathrm{N}$-Acetylcysteine co administration provides potential protection against these changes.

\section{RECOMMENDATIONS}

1. Improvement of health education programs to increase public awareness about health impact of $\mathrm{TiO}_{2}$ nanoparticles through nonessential drug additives, food colors, toothpastes etc. to limit their ingestion.

2. Continuous monitoring of work environment level of nano-titanium to control occupational exposure to $\mathrm{TiO}_{2} \mathrm{NPs}$ and keep it within the recommended exposure limits.

3. Periodic examination of complete blood cell count and differential count in those who are occupationally exposed to $\mathrm{TiO}_{2}$ NPs.

4. Further studies are needed to evaluate mechanisms of $\mathrm{TiO}_{2}$ nanoparticles induced immunotoxicity at molecular level.

5. Novel alternative safe food color, additives should be explored

6. N-acetylcystiene could be used as supplement to occupationally exposed workers.

7. Nanoparticles should be used cautiously to gain its benefits and avoid possible hazards.

\section{REFERENCES}

1. Abdel Azim,S.A.; Darwish,H.A.; Rizk,M.Z.; Ali, S.A. and Kadry, M.O. (2015): Amelioration of titanium dioxide nanoparticlesinduced liver injury in mice: possible role of some antioxidants, Exp Toxicol Pathol., 67: 305-314.

2. Brunet, L.; Lyon, D.; Hotze, E.M.; Alvarez, P.J.J and Wiesner, M.R. (2009): Comparative photoactivity and antibacterial properties of C60 fullerenes and titanium dioxide nanoparticles. Environ Sci Technol., 43: 4355-4560.

3. Bu, Q.; Yan, G. and Deng, P.(2010): "NMR-based metabonomic study of the sub-acute toxicity of titanium dioxide nanoparticles in rats after oral administration," Nanotechnol., 21(12) :125-105.

4. Chen, J.; Dong, X.; Zhao, J. and Tang, G. (2009): In vivo acute toxicity of titanium dioxide nanoparticles to mice after intraperitoneal injection, J. Appl Toxicol., 29, (4): 330-337.

5. Chen, Z .; Wang, Y.; Zhuo, L.; Chen, S.; Zhao, L.; Luan, X.; Wang, H. and Jiaa, G. (2015): Effect of titanium dioxide nanoparticles on the cardiovascular system after oral administration. Toxicol Lett., 239 : 123-130.

6. Chen, Z.; Wang, Y.; Ba, T.; Li, Y.; Pu, J.; Chen, T.; Song, Y.; Gu, Y.; Qian, Q.; Yang, J. and Jia, G.( 2014): Genotoxic evaluation of titanium dioxide nanoparticles in vivo and in vitro. Toxicol. Lett., 226: 314319.

7. Colvin, V. L. (2003): The potential environmental impact of engineered nanoparticles. Nat. Biotechnol.; 21:1166-1170.

8. Cui, Y.; Liu, H.; Zhou, M.; Duan, Y.; Li, N.; Gong, X.; Hu, R.; Hong, M.and Hong, F.( 2011): Signaling 
pathway of inflammatory responses in the mouse liver caused by $\mathrm{TiO} 2$ nanoparticles. J. Biomed. Mater. Res., 96: 221-229.

9. Djordjevich, D.M.; De Luka, S.R.; Milovanovich, I.D.; Jankovic, S.; Stefanovic, S.; Veskovic-Moracanin, S.; Cirkovic, S.; Ilic, A.Z.; RisticDjurovic, J.L.; Trbovich, A.M.( 2012):Hematological parameters' changes in mice subchronically exposed to static magnetic fields of different orientations. Ecotoxicol Environ., 81: 98- 105.

10. El-Kirdasy, A.F.; Nassan, M.A.; Baiomy, A.A.; Ismail, T.A.; Soliman M.M. and Attia, H.F. (2014): Potential ameliorative role of $\mathrm{N}$ acetylcysteine against testicular dysfunction induced by titanium dioxide in male albino rats. American J. Pharmacol Toxicol., 9 (1): 29-38.

11. El-Sayed, E.S.M.; Abdel-Aziz, A.A.H.; Helal, G.K.; Saleh; S. and Saad, A.S. (2010): Protective effect of $\mathrm{N}$-acetylcysteine against carmustineinduced myelotoxicity in rats. Food and Chem Toxicol., 48: 1576-1580.

12. Fabian, E.; Landsiedel, R.; MaHock, L.; Wiench, K.; Wohlleben, W. and van Ravenzwaay, B. (2008): Tissue distribution and toxicity of intravenously administered titanium dioxide nanoparticles in rats. Archives Toxicol., 82(3): 151-157.

13. Fu, Y.; Zhang Y.; Chang, X.; Zhang, Y.; Ma, S.; Sui, J.; Yin, L.; Pu, Y. and Liang, G.(2014): Systemic immune effects of titanium dioxide nanoparticles after repeated intratracheal instillation in rat, Int $\mathrm{J}$ Mol Sci., 15(4): 6961-6973.

14. Giovanni, M.; Yue, J.; Zhang, L.; Xie, J.; Ong, C.N.and Leong, D.T. (2015): Pro-inflammatory responses of RAW264.7 macrophages when treated with ultralow concentrations of silver, titanium dioxide, and zinc oxide nanoparticles. J Hazard Mater.,
297: 146-152.

15. Gustafsson, A.; Lindstedt, E.; Elfsmark, L.S. and Bucht, A. (2011): Lung exposure of titanium dioxide nanoparticles induces innate immune activation and long-lasting lymphocyte response in the Dark Agouti rat. J Immunotoxicol., 8: 111121.

16. Hassanein, K. and El-Amir,Y. (2017): Protective effects of thymoquinone and avenanthramides on titanium dioxide nanoparticles induced toxicity in Sprague-Dawley rats. Pathol Res Pract., 213: 13-22.

17. Hussain, S.; Vanoirbeek, J.A.; Luyts, K.; De Vooght, V.; Verbeken, E.; Thomassen, L.C.; Martens, J.A.; Dinsdale, D.; Boland, S.; Marano, F.; Nemery, B. and Hoet, P.H.( 2010): Lung exposure to nanoparticles modulates an asthmatic response in a mouse model. Eur Respir J., 37: 299309.

18. Institute of Laboratory Animal Resources (1996): Guide for the Care and Use of Laboratory Animals. (7th ed.). National Academy Press; pp.125. ISBN 0-309-05377-3.

19. Jain, S.; Kumar, C.H.M.; Suranagi, U.D. and Mediratta, P.K. (2011): Protective effect of $\mathrm{N}$-acetylcysteine on bisphenol A-induced cognitive dysfunction and oxidative stress in rats. Food Chem Toxicol., 49: 14041409.

20. Jasmine, J. ; Cheng,T.N. ; Bay, L.B.H. and Yung, L.Y.L. (2010): J. Nucleic Acids;122: 237-288

21. Jin, C.Y.; Zhu, B.S.; Wang, X.F. and Lu, Q.H.(2008): Cytotoxicity of titanium dioxide nanoparticles in mouse fibroblast cells, Chem Res Toxicol., 21( 9): 1871- 1877.

22. Johnson, M. D. (2007): The Rats. In: Animal models of toxicology, Gad SC (ed.), Chapter 3, 2nd edition. CRC Press, Taylor \& Francis Group, LLC, Boca, Raton, London, New York, pp. 
187-188.

23. Li, J.J.; Hartono, D.; Ong, C.N.; Bay, B.H. and Yung, L.Y.L.(2010): Autophagy and Oxidative Stress Associated with Gold Nanoparticles. Biomaterials, 31:5996-6003.

24. Li, N.; Duan, Y.M.; Hong, M.M.; Zheng, L.; Fei, M.; Zhao, X.Y.; Wang, J.; Cui, Y.L.; Liu, H.T.; Cai, J.W.; Gong, S.J.; Wang, H. and Hong, F.S.(2010): Spleen injury and apoptotic pathway in mice caused by titanium dioxide nanoparticules, Toxicol Lett., 195 (2-3): 161-168.

25. Li, S.Q.; Zhu, R.R.; Zhu, H.; Xue, M.; Sun, X.Y.; Yao, S.D. and Wang, S.L. (2008): Nanotoxicity of $\mathrm{TiO}_{2}$ nanoparticles to erythrocyte in vitro. Food Chem Toxicol., 46: 3626-363.

26. Luo, Y.; Liu, H.; Rui, Q. and Tian, Y.( 2009): Detection of extracellular $\mathrm{H}_{2} \mathrm{O}_{2}$ released from human liver cancer cells based on $\mathrm{TiO}_{2}$ nanoneedles with enhanced electron transfer of cytochrome c. Anal Chem., 81: 3035-3041.

27. Magaye, R., Zhao, J., Bowman, L. and Ding, M. (2012): Genotoxicity and carcinogenicity of cobalt-, nickeland copper-based nanoparticles. Exp Ther Me., 4:551-561.

28. Manosij, G., Anirban, C. and Anita, M. (2013): Cytotoxic, genotoxic and the hemolytic effect of titanium dioxide (TiO2) nanoparticles on human erythrocyte and lymphocyte cells in vitro. J app toxico., 10971110.

29. Markowska-Szczupak, A.; Ulfig, K. and Morawskia, A.W. (2011): The application of titanium dioxide for deactivation of bio particulates: an overview. Catalysis Today, 169: 249257.

30. Maynard, A.M. and Kuempel, E.D. (2005): Airborne nanostructured particles and occupational health. J. Nanoparticle Res., 7(6):587-614.

31. Medina, C.; Santos-Martinez, M.J.;
Radomski, O.I.; Radomski, M.W and Corrigan, A. (2007): Nanoparticles pharmacological and toxicological significance. $\mathrm{Br} \quad \mathrm{J}$ Pharmacol., 150:552-558

32. Montazer, M. and Seifollahzadeh, S. (2011): Enhanced self-cleaning, antibacterial and UV protection properties of nano $\mathrm{TiO}_{2}$ treated textile through enzymatic pretreatment. Photochem Photobiol., 87: 877-883.

33. Nel, A.; Xia, T.; Madler, L. and Li, N. (2006): Toxic potential of materials at the nanolevel. Science, 311: 622627.

34. Nemmar, A.; Melghit, K. and AlSalam, S. (2011): Acute respiratory and systemic toxicity of pulmonary exposure to rutile Fedoped $\mathrm{TiO}_{2}$ nanorods Toxicol., 279 (1-3): 167175.

35. Oberdörster, G.; Oberdörster, E. and Oberdörster, J. (2005): Nanotoxicology: An Emerging Discipline Evolving from Studies of Ultrafine Particles Environmental Health Perspectives, 113:823-839.

36. Palomäki, J.; Karisola, P.; Pylkkanen, L.; Savolaninen, K. and Alenius, H. (2010): Engineered nanomaterials cause cytotoxicity and activation on mouse antigen presenting cells. Toxicol., 267(13):125-131.

37. Park, E.J.; Yi, J.; Chung, K.H.; Ryu, D.Y.; Choi, J. and Park, K. (2008): Oxidative stress and apoptosis induced by titanium dioxide nanoparticles in cultured BEAS-2B cells. Toxicol Lett., 180: 222-229.

38. Park, E.J.; Yoon, J.; Choi, K.; Yi, J. and Park, K.(2009): Induction of chronic inflammation in mice treated with titanium dioxide nanoparticles by intratracheal instillation. Toxicol., 260: 37-46.

39. Riu, J.; Maroto, A. and Rius, F.X. (2006): Nanosensors in environmental analysis. Talanta, 69 (2):288-301. 
40. Robertson, T.A.; Sanchez, W.Y. and Roberts, M.S. (2010): Are commercially available nanoparticles safe when applied to the skin? J Biomed Nanotech., 6: 452-468.

41. Roco, M.C. (2007): National Nanotechnology Initiative Past, Present, Future. In: Handbook on Nano science, Engineering and Technology. Taylor and Francis Group; Oxford; UK; $2^{\text {nd }}$ ed.; pp. 3.13.26

42. Sang, X.; Zhang, Z.and Hong, F. (2012): The chronic spleen injury of mice following long-term exposure to titanium dioxide nanoparticles, $\mathbf{J}$ Biomed. Mater Res., 100: 894-902.

43. Scherbart, A.M.(2011): Contrasting macrophage activation by fine and ultrafine titanium dioxide particles is associated with different uptake mechanisms, Part. Fibre Toxicol., 8 : 31.

44. Shi, H.; Magaye, R.; Castranova, V. and Zhao, J. (2013): Titanium dioxide nanoparticles: a review of current toxicological data. Particle and Fibre Toxicol., 10:15.

45. Shukla, R.K.; Sharma, V.; Pandey, A.K.; Singh, S.; Sultana, S. and Dhawan, A. (2011): ROS-mediated genotoxicity induced by titanium dioxide nanoparticles in human epidermal cells. Toxicol In Vitro, 25: 231-241.

46. Singh, R. and Nalwa,H.S. (2011): Medical applications of nanoparticles. In: Biological imaging, cell labeling, antimicrobial agents, and anticancer Nano drugs. J Biomed Nanotechnol., 7: 489-503.

47. Trouiller, B.; Reliene, R.; Westbrook, A.; Solaimani, P. and Schiestl, R.H. (2009): Titanium dioxide nanoparticles induce DNA damage and genetic instability in vivo in mice, Cancer Res., 69 (22): 87848789.

48. Vamanu, C.I.; Cimpan, M.R.; HI,
P.J.; Srnes, S.; Lie, S.A. and Gjerdet, N.R. (2008): Induction of cell death by $\mathrm{TiO}_{2}$ nanoparticles: studies on a human monoblastoid cell line. Toxicol in Vitro, 22: 1689-1696.

49. Wang, J.X.; Zhou, G.Q.; Chen, C.Y.; Yu, H.W.; Wang, T.C. and Ma, Y.M. (2007): Acute toxicity and biodistribution of different sized titanium dioxide particles in mice after oral administration. Toxicol Lett., 168(2): 176-185.

50. Wiesenthal, A.; Hunter, L.; Wang, S.; Wickliffe, J. and Wilkerson, M. (2011): Nanoparticles: small and mighty. International J Dermatol., 50:247-254.

51. Xue, C.; Liu, W.; Wu, J.; Yang, X. and $\mathrm{Xu}, \mathrm{H}$. (2011): Chemoprotective effect of $\mathrm{N}$-acetylcysteine (NAC) on cellular oxidative damages and apoptosis induced by nanotitanium dioxide under UVA irradiation. Toxicol In Vitro, 25: 110-116.

52. Yuan, Y.; Ding, J.; Xu, J.; Deng, J. and Guo, J. (2010): $\mathrm{TiO}_{2}$ nanoparticles co-doped with silver and nitrogen for antibacterial application. $\mathrm{J}$ Nanosci Nanotechnol., 10: 48684874.

53. Zhang, Y.; Qi, T. and Zhang, Y. (2009): A novel preparation of titanium dioxide from titanium slag. Hydrometallurgy, 96: 52- 56.

54. Zhangjian, C.; Yun, W.; Lin, Z.; Shi, C.;Lin, Z.; Xianguo, L.; Haifang, W. and Guang, Jiaa.(2015): Effect of titanium dioxide nanoparticles on the cardiovascular system after oral administration. Toxicol Lett., 239: 123-130

55. Zhao, J.; Bowman, L.; Zhang, X.; Vallyathan, V.; Young, S.H.; Castranova, V. and Ding, M. (2009): Titanium dioxide ( $\mathrm{TiO} 2)$ nanoparticles induce JB6 cell apoptosis through activation of the caspase-8/Bid and mitochondrial pathways. J. Toxicol 
Environ Health, 72: 1141-1149.

56. Wloelek, D.; Nanall, J. and olive, p. l. (1991): Comparison between pulsed- field and constant field gel electrophoresis for measurement of DNA double strand break. Inl J Readiat Boil, 60 (5) (1991), pp. 779 790

57. Buffone and Darlington (1985): Isolation of DNA from biological specimens without extraction with pheanel Clin chem., 31: 164-165.

58. Burton, K. (1956): Astrudy of the condition and mechanism of the diphenylamine reaction of colorimetric of deoxy ribonucleic acid. Biocher., 62: 315

59. Perandones, C.E.; Illera, V. A., peckham, D.; stunz, L.L and Ashman, R. F. (1993): Regulation of apoptosis in vitro in mature murine spleen Tcell J Immunol., 151 (7) 3521 -3529 . 
فعالية عقار "ان-أسيتيل سيستين" على السمية المناعية المحدثة بجزيئات "ثاني أكسيد التيتانيوم النانووية" في الجرذان البيضاء البالغة

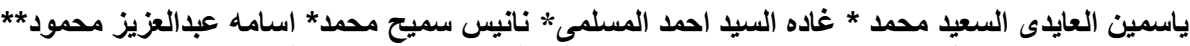

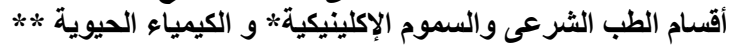 \\ كليه الطب البشرى- جامعة الزقازيق- مصر
}

مقدمة البحث: ثاني أكسيد النتبانيوم هو اكسيد طبيعي للنيتانيوم يوجد في ثلاثة أثنكال: الروتيل والاناتاز والبروكيت وهو يستخدم على نطاق واسع مثل التطهير

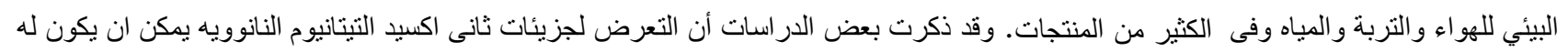

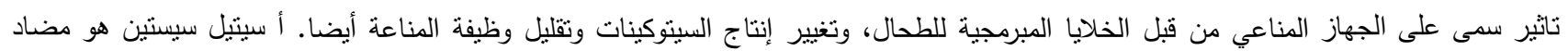

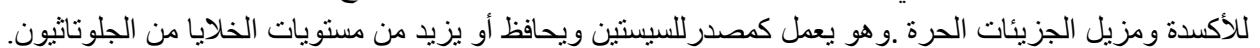

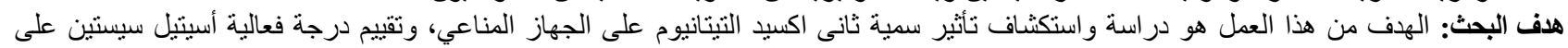

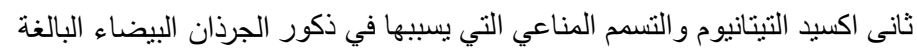

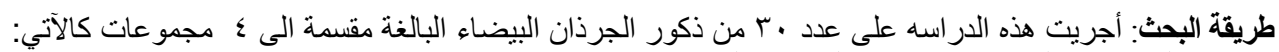

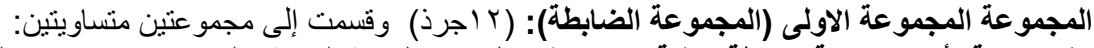

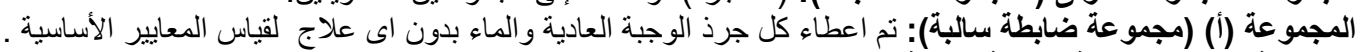

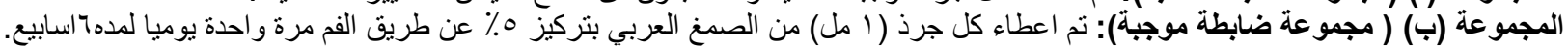

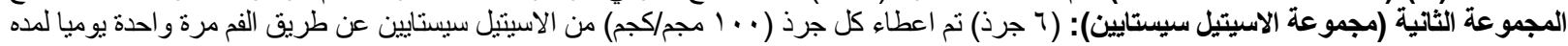
المجوعة اسبيع. المجموعة الثالثة (مجموعة ثاني أكسيد التيتانيوم):( ج جرذ) نم اعطاء كل جرذ ( . . ب ا مجم/كجم) من ثاني أكسيد التيتانيوم ذو الجزيئات متناهيه

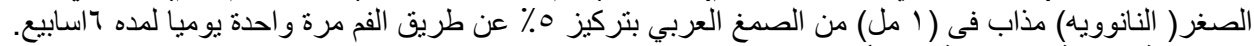

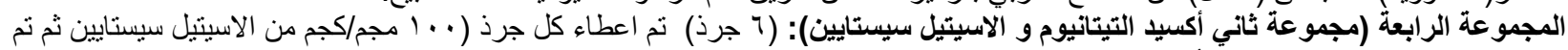

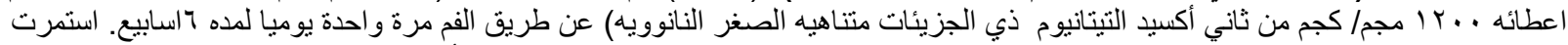

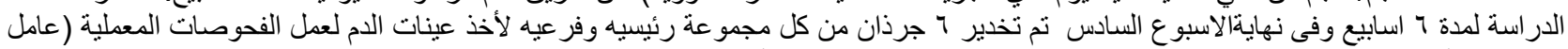

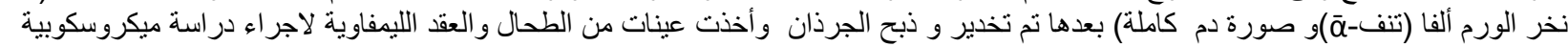

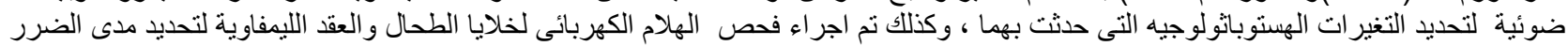

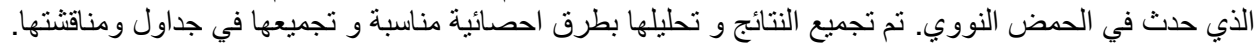

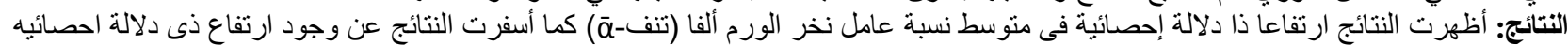

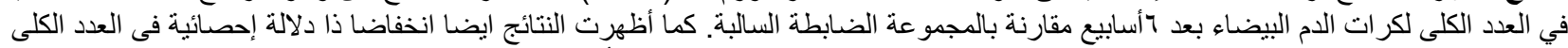

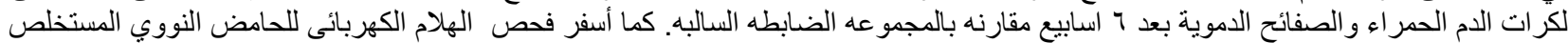

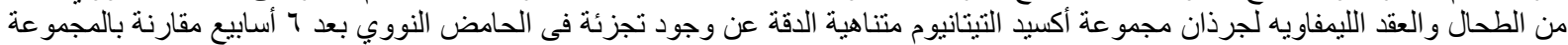

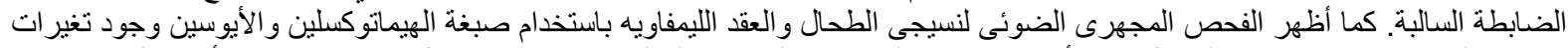

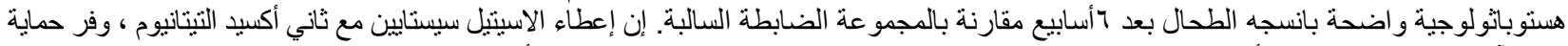

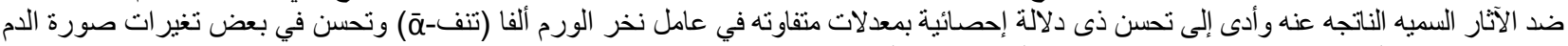

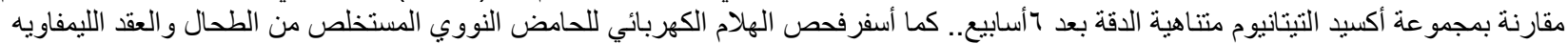

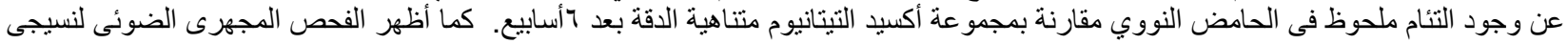

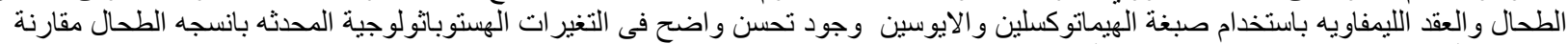

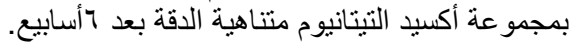

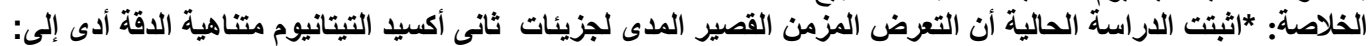

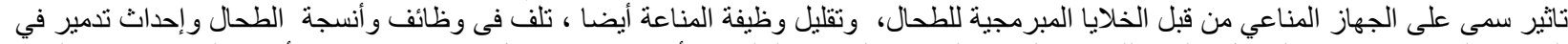

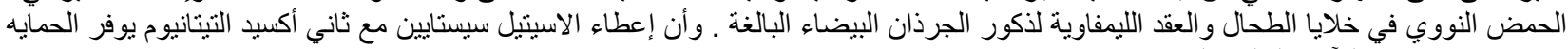

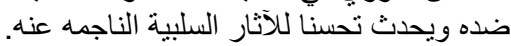

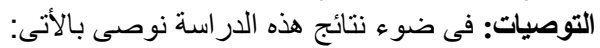

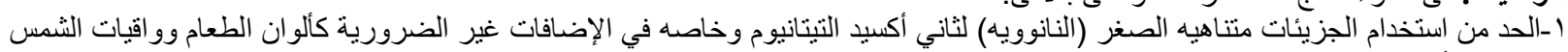

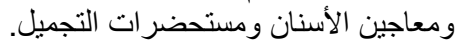

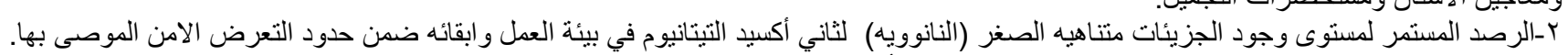

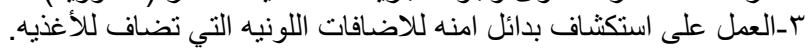

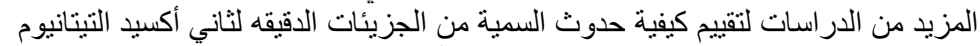

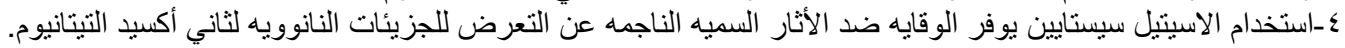

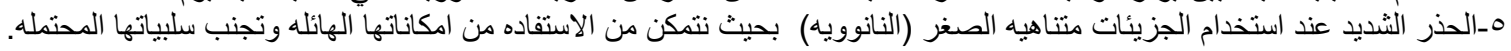

